This article has been published as: Van Staveren, Irene,

'Caring Finance Practices', Journal of Economic Issues 47 (2), 2013, pp. 419-425.

Please if you quote, use the published version.

\title{
CARING FINANCE PRACTICES
}

\begin{abstract}
The 2008 financial crisis has demonstrated the failure of both utilitarian and deontological ethics in finance. Alternatives do not need to be created from nothing, because the crisis itself has stimulated the emergence of ethically sound finance practices from within the sector. This article presents two cases of such alternatives, which can be understood as caring finance. Caring finance is built around more personal relationships, responsibility, and risk reduction. The examples are from the Netherlands and concern capital financing in a large, international cooperative bank and crowd funding for an organic farm respectively. The case studies cannot replace regulation, but they are feasible complements to regular financial routines, with good private and social returns.
\end{abstract}

Keywords: caring finance, crowd funding, ethics, Rabobank, the Netherlands

JEL Classifications Codes: A13, D63, G21, G23 
In an analysis of the ethics of the 2007 financial crisis Crespo and van Staveren (2011) have argued that the causes of the crisis lie in a utilitarian framework, whereas a deontological approach, relying on rules, duties, and universalism, has fallen short to prevent the crisis and is likely to be inadequate to prevent another one of comparable impact. A third ethical perspective that we presented is that of caring, recently developed in ethics, particularly in feminist ethics (Gilligan, 1986; 1994; Held, 2006). Whereas utilitarianism relies on autonomy and maximizing happiness for the greatest number, deontology is concerned with what is the right principle of action for everyone. The ethics of care is concerned with maintaining relationships through whuich we care about each other. The central value of care is responsibility, which is both a contextual value (unlike a principle or rule) and a relational value (unlike autonomy or maximization based on self-interest).

The ethics of care as applied to finance hence relies on the value of responsibility in financial relationships. Caring finance means taking a long-term perspective for sustaining these relationships, and is concerned with reducing risk from the recognition that finance is vulnerable to a high degree of uncertainty and may affect people in many unexpected ways. Caring finance, therefore, involves a very different set of routines as compared to finance based on maximization of selfinterest, or rule-based finance.

Some of the new initiatives in finance seem to express already an ethics of care perspective. This implies that such alternatives do not need to be built from zero. In this paper, I present two case studies of financial innovation in the Netherlands since the crisis. I argue that these are examples of an ethics of care perspective in finance. I will do this through thick descriptions of the two cases. The first case study 
is based on an extensive open interview with two experts in the treasury of a large cooperative bank, added with information from the media and a recent book on the bank. The second is based on a combination of participant observation in a crowd funding project, in which I have invested a small amount of money, and a semistructured interview with the farmer couple who use the crowd funding, with in addition calculations with data that I have collected from price lists of the farm's products and of organic food shops.

\section{Contingent, cooperative capital ${ }^{1}$}

This first case study analyzes a new capital funding product that a major Dutch bank has developed in response to the crisis and which has attracted much attention from investors and regulators worldwide. It was developed by two senior bankers, in the context of regulatory pressure, limited liquidity in a hesitant capital market, in a cooperative bank structure with a client/member-value orientation.

Rabobank, a top three Dutch bank and market leader in savings, mortgages, and agricultural lending in the Netherlands, has issued an innovative form of senior debt, a Senior Contingent Note (SCN) in $2010^{2}$. The SCN is in first instance a way to raise capital for the bank through bonds. The value of the bond does not appear on the balance sheet unless the bank's equity capital ratio would to fall below $7 \%$. In that very unlikely case the bank's core capital will be strengthened as the bank will receive $75 \%$ of the value of the outstanding SCNs. Hence, those who bought the bond will lose $75 \%$ of their investment ${ }^{3}$. In exchange for that risk, the interest rate that bondholders receive includes a risk premium. 
Rabobank is the only large Dutch bank that did not need state support, that kept its triple A rating throughout the crisis, merely dealing with collateral damage spilling over from other banks. Rabobank is a cooperative bank, so it cannot raise capital through issuing shares ${ }^{4}$. Although about $85 \%$ of Rabobank's activities are in the Netherlands, half of its capital is raised abroad. The major way in which the bank raises its capital is simply through retained profit, while issuing certificates to its members (individuals and small and medium enterprises) is another recent innovation of the bank to raise capital. But that is small scale and through the local, independent branches and their local members. The SCN targets large investors such as pension funds and globally operating investment funds.

The SCN was not developed at the international branch of the bank, where the financial traders are based. Instead, the new type of bond was developed at the treasury of the bank, as part of the long term funding strategy. The challenge during the crisis was how to get access to liquidity in a drying up market (which in Europe was extra hit by the sovereign debt problem) on the one hand and staying true to the bank's conservative capital position, which had earned the bank its triple A rating throughout the crisis. The strength of a cooperative bank is precisely its prudence - its higher than average equity capital ratio, as compared with most other banks, which gives it a boring image in booming years. This asset - prudence - was the basis for developing the SCN, which nevertheless did not obtain a rating ${ }^{5}$. The product was developed internally with consultation of a few large investors. Whereas Rabobank initially planned a $100 \%$ core capital strengthening with the new product, investors made clear that that would be unacceptable by the market. A different case of Lloyd's in London half a year earlier ${ }^{6}$, as well as past cases of defaulting banks across the 
globe have led to the current $75 \%$ ratio of the SCN to be added to the balance sheet in case the bank's equity capital ratio would fall below 7\%. The investors run a risk and contrary to shareholders, they do not benefit from more risky projects undertaken by the bank that may bring in more short term profits, instead, they will demand that the bank either increases its buffers or raises the premium on newly issued contingent notes. The interest rate was not discussed at these sounding board meetings with investors, until the last week before the transaction on March $12^{\text {th }} 2010$ in a meeting with four major investors. The interest among institutional investors as well as private investment funds was overwhelming, both nationally and internationally (London, Paris, Frankfurt, New York) so that the transaction of the 10 year fixed rate Senior Contingent Note, priced at an annual coupon of $6.875 \%$ was twice oversubscribed, and generated 1.25 billion euro.

So, prudence - by putting the responsibility for risk where it should be, namely the providers of capital - made it possible to find a market for this product. And it does not only contribute to lower risk and more stability of the bank itself, but also at the systemic level. In case of a too low capital ratio of Rabobank, the $75 \%$ shift of the loan to the balance sheet increases the equity capital ratio automatically, so that the bank does not (immediately) require financial support by the state, and hence is not a burden on taxpayers. Moreover, the $\mathrm{SCN}$ helps to reduce the likeliness of another deep crisis because it forces banks to keep risks relatively low in order to prevent the equity capital ratio to go down too much: that would lower demand for this type of bond and hence limit the possibility of banks to acquire equity. This feature of the development of SCN hence can be characterized as one of a long run view, as a concern with financial market volatility and effective responses to this from 
the banking sector itself - an attitude of responsibility. Not the kind of self-sacrificing responsibility as in stopping a fight at risk of your life, but the kind of responsibility as part of a liberal attitude, accepting the consequences of one's individual actions for the whole, participants (like clients and investors) and non-participants who bear negative externalities (like the tax payer). It is the responsibility that Adam Smith wrote about, that does not constrain markets but rather supports the effective functioning of markets. SCN expresses such responsibility because it is a selfregulating instrument against too high risk positions by banks and prevents costly bail-outs and compensation of clients' deposits in times of crisis. It is, in the end, a mechanism that puts the risk where it should be, namely by the capital providers of banks, rather than its clients or the taxpayer.

Finally, why was it a cooperative bank to develop this innovation? Why not an equally big bank listed on the stock exchange, such as ING? This has only indirectly to do with the cooperative structure of the bank. The idea did not come from the member council, not the local ones, neither from the central membership council. So, as much as the bank is driven by client-value through close contact with its members and other clients, this did not play a role in the SCN. But it was the lack of access to capital through shares that drove the bank's treasury to be innovative and to develop a product that would on the one hand build on its conservative position and on the other hand even strengthen its image in the market as a prudent bank, by providing an extra buffer for its capital ratio. In the words of one of the interviewees: "we do not have the shareholders pressure, which is an enormous benefit" and thereby it also "protects against moral hazard internally" and "pushes to be creative to raise capital if you can't do it through equity". This confirms Keynes' insight that it is the capitalist system 
based on equity capital which generates the uncertainty and subsequent systemic risk in financial markets, as Skidelsky (2009: 84) reminds us: "Under capitalism, uncertainty is generated by the system itself, because it is an engine for accumulating capital goods whose rewards came not now but later. The engine of wealth creation is at the same time the source of economic and social instability."

\section{Crowd funding for a green future}

The second case study is on a community-based form of finance, which allows the funding of innovative activities in which banks and governments are reluctant to invest. The reasons for this reluctance relate to perceived high risks, lack of knowledge about the innovative area of activity, or a general low supply of credit due to the credit crunch following the financial crisis. Interestingly, crowd funding can generate both high rates of social return as well as high rates of private return on investment, due to strong synergies of combining the force of the market with the strength of civil society - led by the social values of the latter.

I have carried out a case study of a crowd funding project in the Netherlands, which combines the social aim of a transition to a green economy with a private return on investment that lies above the market rate in most economic sectors at the moment. The project concerns consumers financing solar energy panels for farms, with a return on investment paid in farm products. The two farmers of the particular project I studied, Koos and Monique, run an organic milk farm, 'De Beekhoeve', in a small village in the province of Utrecht, with 60 cows. They sell the milk through an association of organic milk farmers in the Netherlands, to regular as well as organic supermarkets. Their other products, which are also organic - including meat, cheese, 
apple juice, and ice cream - are sold at the farm and to shops and restaurants in the neighbourhood, stimulating the local economy.

Monique and Koos decided to invest in solar panels on the roof of the cow shed, during the financial crisis in 2008. They already had taken bank credit for earlier investments and looked for an alternative credit opportunity. They found a recently set-up crowd funding initiative called 'Boer zoekt Buur' ${ }^{7}$. The participation is by 27 organic farms and 750 investors/consumers ('neighbours'). The project offered shares worth 250 euro each. In return, investors/consumers receive six vouchers of 50 euro each, to be spent on the products on the farm of their choice, one per year. This is a return on investment of 3 percent annually. There are additional advantages for both farmers and consumers. For the farmers: the investment does not require pay back in money, from profits, and hence saves money for other expenditures. Instead, the arrangement to pay back in products ensures the farmers a fixed minimum demand and an increase in volume sold, helping to attain economies of scale.

30 consumers participated in the solar energy investment on the farm of Koos and Monique. This resulted in 50\% financing of the investment through the project, with the other $50 \%$ financed through the farmers' savings and a small bank loan. The disadvantage of the project is that the farmers have a higher administrative load as compared to a bank loan, because of the smaller number of investors. The advantage, however, of this personalized investment relationship is more contact between farmer and 'neighbor', which was one of the objectives of the project, and a means to support sustainable farming in society through strengthening consumer ties with organic agriculture. This is also enabled through additional participatory economic activities 
such as voluntary work at the farm and the adoption of cows in exchange for regularly updated information about the cow's wellbeing.

The additional advantages for the consumer are first that consumers know where their food originates, by visiting the farm in person when collecting their products on an annual basis. Second, they benefit from the price difference in organic products sold in organic or regular shops and lower wholesale prices at the farm gate. To give an indication of the price advantage, the table below shows the price differences of the major types of meat and the other products sold at 'De Beekhoeve' and in shops in the Netherlands. The average weighted price advantage for consumers is 30 percent.

Table Organic product prices in the Netherlands, 2011, per kilogram.

\begin{tabular}{|l|l|l|l|}
\hline Product & Shop prices & Prices at 'De & Price difference per \\
& & Beekhoeve' & kilogram (\%) \\
\hline Meat loaf & 11,00 & 9,50 & $-14 \%$ \\
\hline Entrecote & 21,90 & 23,00 & $+5 \%$ \\
\hline Rib-eye & 23,50 & 19,00 & $-19 \%$ \\
\hline Steak & 28,50 & 23,00 & $-19 \%$ \\
\hline Tournedos & 53,50 & 35,00 & $-35 \%$ \\
\hline Sausage & 25,20 & 13,50 & $-46 \%$ \\
\hline Apple juice (1 1.) & 1,45 & 2,00 & $+38 \%$ \\
\hline Walnuts & 9,98 & 6,00 & $-35 \%$ \\
\hline Cheese (young) & 11,30 & 13,00 & $+12 \%$ \\
\hline Av. weighted price difference & & & \\
\hline
\end{tabular}

Data sources: websites of 'De Beekhoeve', butcher chain De Groene Weg, Rotterdam, regular supermarket Albert Heijn and organic supermarket Eko Plaza, 2011. 
In conclusion, the 'Boer zoekt Buur' project reduces pay back risk by providing consumers with vouchers for six years rather than requiring pay back out of volatile financial returns, while in the case of bankruptcy, the 'neighbours' may collectively offer voluntary labour for the survival (farm work) and future strategy (management advise) of the farm. The project provides access to alternative finance to the farm and provides a secure minimum in sales contributing to the realization of economies of scale. While the investors/consumers reap a return on investment of $3 \%$ plus a price advantage of $30 \%$ for trustworthy organic food products with known origin. The positive externality, or social return, is threefold. First, low-carbon energy generation, second, consumer and investor support for a transition to a green economy through the commitment built between farm and neighbors and third, lower risk levels because of transparency, no leverage, pay-back in goods produced with high fixed and low variable costs, and the potentiality of emergency labour and management advice.

\section{Conclusion}

The two case studies do not fit a utilitarian perspective: they are not concerned with individual performance of a firm and their primary objective was not concerned with profit maximization. They also do not easily sit in a deontological approach, because they did not follow from external regulation or firm-level rules and are not universally applicable throughout the financial sector. Instead, the cases are highly contextual, build on relationships of responsibility, and are risk reducing at the firm level as well as at the systemic level. 
Obviously they have their weaknesses, such as a strong reliance on trust and relatively slow transferability of the assets concerned. Moreover, they cannot replace rules. Regulation is necessary, for example to prevent that the caring instrument of SCNs becomes part of derivatives and speculation on the demand side of the market. But rules are not sufficient to prevent a next deep crisis. The examples of emerging caring finance practices show that they are feasible complements to both utilitarian and deontological financial routines, combining above-market levels of returns on investment with relatively high social returns of stability and sustainability.

\section{References}

Crespo, Ricardo, and Irene van Staveren (2012) 'Would We have had this Crisis if Women had been Running the Financial Sector?', Journal of Sustainable Finance and Investment 1 (3-4), pp. 241-250.

Gilligan, Carol, 1982. In a Different Voice. Psychological Theory and Women's Development. Cambridge (MA): Harvard University Press.

Held, Virginia (2006) The Ethics of Care. Personal, Political, and Global. Oxford: Oxford University Press.

Levinson, Marc (2010) 'Faulty Basel. Why More Diplomacy Won't keep the Financial System Safe', Foreign Affairs 89 (3).

Mooij, Joke, and Wim Boonstra (eds.) (2012) Raiffeinsen's Footprint - The Cooperative Way of Banking. Amsterdam: VU University Press. 
Skidelsky, Robert (2009) Keynes. The Return of the Master. London: Allan Lane.

\section{Notes}

${ }^{1}$ This case study is based on information released through the media, a presentation for investors, and an interview I held with the two key persons who developed the SCN in the Treasury Rabobank Group, Utrecht, $18^{\text {th }}$ of May, 2010.

${ }^{2}$ The transaction date was $12^{\text {th }}$ of March 2010, at the amount of 1.25 billion euro for a 10 year fixed rate priced at an annual coupon of $6.875 \%$.

${ }^{3}$ In the past, convertible bonds were labeled as Tier 2 capital and institutional lenders were often supported in a bail-out (Levinson, 2010). With SCNs in the new situation after the crisis, it is less likely that regulators will protect these types of capital.

${ }^{4}$ The bank has 1.8 million members, which is a non-financial membership for any client but involves no claim on the equity of the 147 local banks. It is globally number one in several countries in the food- and agri-business and has 623 foreign offices in 48 countries. The maximum bonus for senior management and executives is $30 \%$ of the salary and half of the bonus is transferred only after three years. For a recent academic publication on the operation and performance of Rabobank during the crisis, see Mooij and Boonstra (2012).

${ }^{5}$ The top three international rating agencies did not want to assign a rating to the SCN, since they preferred to await new international regulation coming from Basel.

${ }^{6}$ Lloyd's is a listed bank, which failed to raise sufficient capital through issuing new shares. Hence, it issued contingent notes that would be turned into equity in case of pre-defined stress.

${ }^{7}$ Dutch for "Farmer wants Neighbour', and a variation of the title of a popular TV dating show in the Netherlands, running in more than twenty five countries across the world, 'Boer zoekt Vrouw' (Farmer wants Wife'). The project was initiated by Triple I-S, green energy supplier Greenchoice, and VSB fonds. 